This pdf of your paper in Journal of Roman Pottery Studies Volume 17 belongs to the publishers Oxbow Books and it is their copyright.

As author you are licenced to make up to 50 offprints from it, but beyond that you may not publish it on the World Wide Web until three years from publication (April 2021), unless the site is a limited access intranet (password protected). If you have queries about this please contact the editorial department at Oxbow Books (editorial@oxbowbooks.com). 


\title{
A Late Iron Age and early Roman pottery assemblage from Leybourne Grange, West Malling, Kent
}

\author{
Edward Biddulph \\ with a contribution by Sean Patrick Quinn
}

\begin{abstract}
Some 3500 sherds of pottery were recovered from excavations by Oxford Archaeology at Leybourne Grange, near West Malling in Kent. The assemblage spanned the Late Iron Age to early Roman period and was indicative of a basic-level rural settlement, although small amounts of imported amphorae, Gallo-Belgic wares and samian wares also recorded suggest that the settlement was situated within wider trading networks. A notable aspect of the assemblage was the presence of pottery tempered with rock fragments identified by petrographic analysis as sandstone. The pottery, hitherto not recognised in the region, is likely to have been locally made, the sandstone having derived from the Hythe Formation, which forms part of the geology of the site. Despite the availability of the stone, sandstone-tempered pottery appears to have been a short-lived phenomenon, perhaps relating to a period of experimentation during a time of flux in ceramic traditions. This paper describes and discusses the sandstone-tempered pottery in its ceramic and regional context, and examines themes of pottery supply, deposition and settlement status.
\end{abstract}

Keywords: Kent; settlement archaeology; Late Iron Age; early Roman period; pottery; imports

\section{Introduction}

The site of Leybourne Grange is located to the west of Leybourne village near West Malling in Kent (NGR: TQ 678 593), and to the south of the M20 motorway within the grounds of a former hospital (Fig. 1). Excavations were undertaken in four areas (A to D) in the southern part of the site in 2009 by Oxford Archaeology in advance of residential development. A watching brief was subsequently maintained by Oxford Archaeology on other areas, though archaeological remains were confined to one area (E).

Residual worked flint, including a polished axehead, points to Neolithic activity in the area, and more worked flint and pottery tentatively dated a ditch in Area $\mathrm{D}$ to the Late Bronze Age. The most significant activity, however, dated from the Late Iron Age to early Roman period. In Area A, a large enclosure, which contained pits and a fourpost structure, was established in the late first century BC or early first century AD. This was replaced by a second enclosure, which contained a group of inter-cutting pits. Pottery suggests that the ditches were infilled within a few decades following the Roman invasion of AD 43. A series of Late Iron Age and early Roman narrow field or boundary ditches were recorded in the southern part of Area A and Area D. Another enclosure, dated to the Late Iron Age, was recorded in Area E.
Significant amounts of pottery - mainly locallyproduced, but also including imported amphorae and Gallo-Belgic wares - were recovered from both the ditches and pits. Together the excavated evidence suggests a rural settlement of relatively low status. A notable aspect of the ceramic assemblage was the presence of a coarseware type, apparently introduced in the Late Iron Age, which was tempered with rock fragments. These have been identified as sandstone. The choice of sandstone as a filler within the pottery of the region, at this time dominated by grog-tempered tradition, with 'Romanized' sand-tempered fabrics beginning to emerge, is unusual and may represent opportunistic use of local resources, if not a degree of experimentation.

The pottery is described below along with the rest of the pottery assemblage. A detailed site report, containing a full description of the archaeology encountered, as well as artefactual and environmental reports, is available to download from Kent Archaeological Reports online (Biddulph 2017).

\section{The assemblage, methodology and fabrics}

\subsection{The assemblage}

A total of 3591 sherds with a weight of $46,873 \mathrm{~g}$ were recovered from the excavation. A further 221 sherds, 


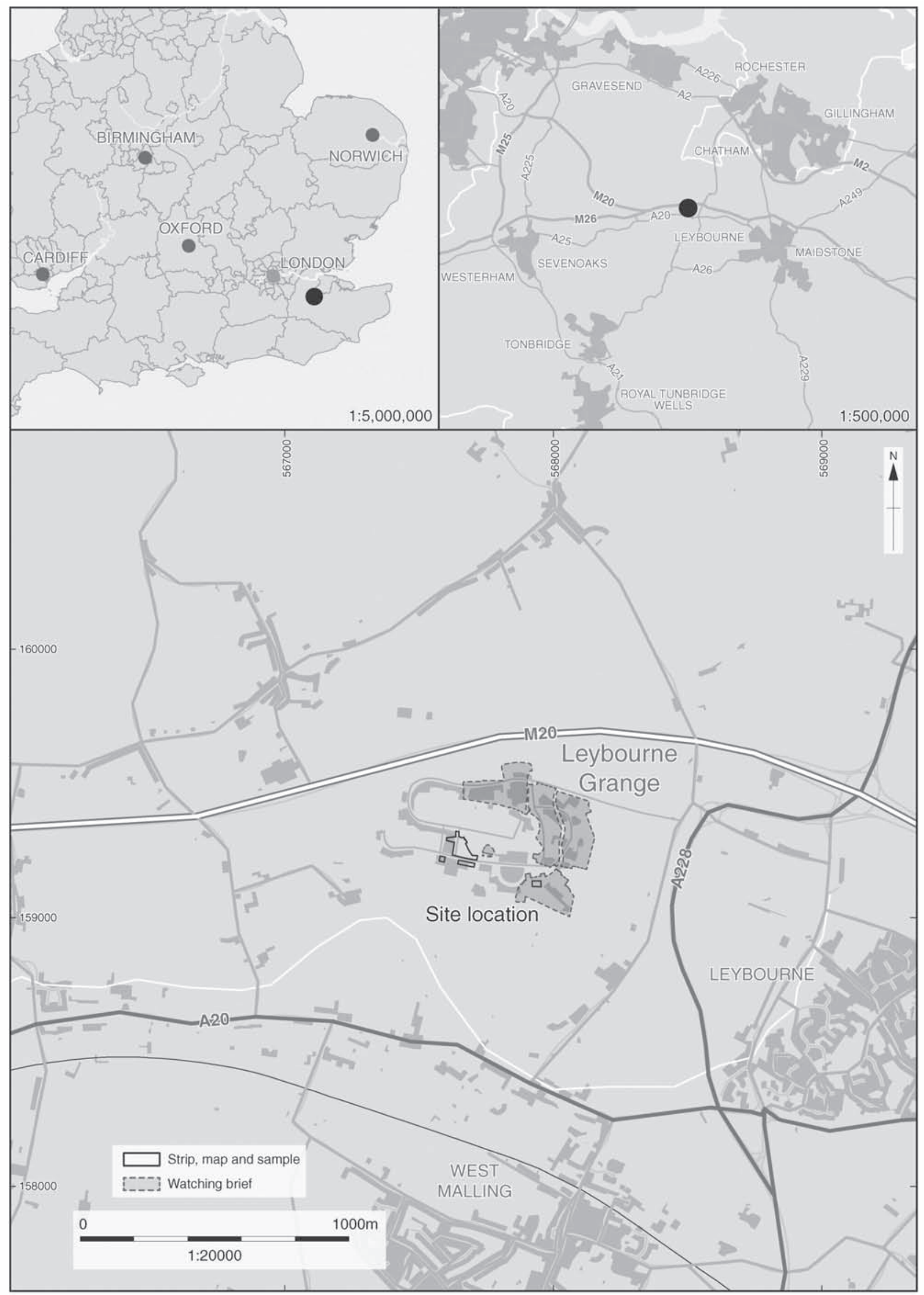

Figure 1. Site location maps, showing the areas where the archaeological investigations and monitoring were undertaken (by strip, map and sample excavation work and the areas covered by watching brief). 


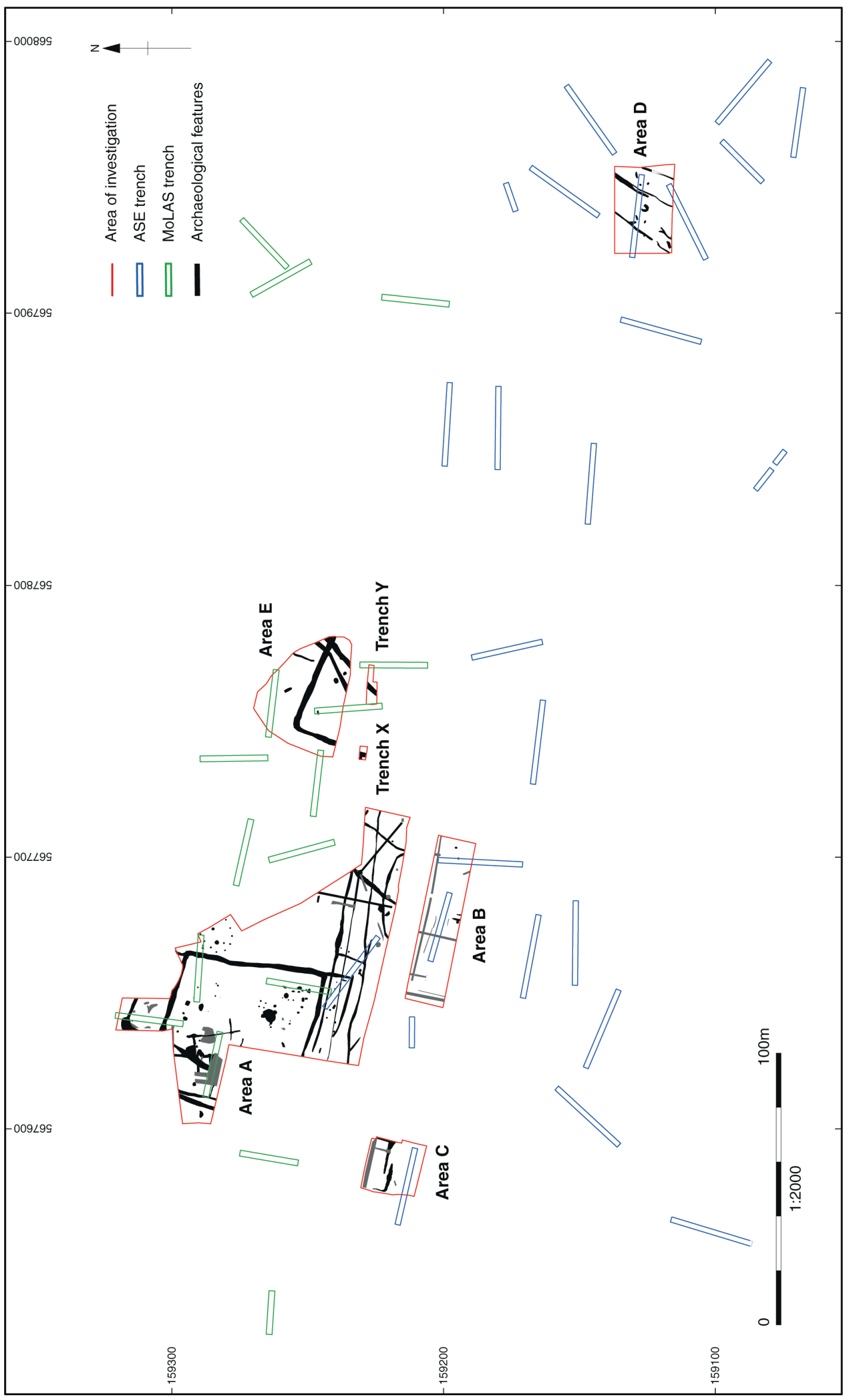


weighing $3210 \mathrm{~g}$, were collected from a subsequent phase of watching brief. The assemblage consists almost exclusively of Late Iron Age and early Roman pottery dating up to $c$ AD 50/70. A small quantity of sherds is of earlier date, probably Late Bronze Age/ Early Iron Age, and a single post-medieval fragment was also noted.

The assemblage derived from 135 contexts, producing context groups which varied very considerably in size. The average size of group was 371g. The largest group (1210) weighed $c 8900 \mathrm{~g}$, but including this only four context groups produced more than $2000 \mathrm{~g}$ of pottery. Fifty-five context groups produced less than $50 \mathrm{~g}$ of pottery each. The condition of the material was also variable. Surface condition ranged from good to poor, and some sherds were worn, although relatively few sherds were heavily abraded.

\subsection{Methodology}

The assemblage was sorted within context groups into fabrics and then into sherd groups, that is to say, collections of sherds sharing certain characteristics, such as rims belonging to the same vessel or pieces with particular decoration, or simply a mass of undiagnostic body sherds of identical fabric. Each sherd group was quantified by sherd count, weight, and where rims were present estimated vessel equivalents (EVE), which records the surviving percentage of a complete rim (here expressed in decimal form, hence 0.25 EVE equals $25 \%$ ), and minimum number of vessels (MNV) based on rim count. Vessel types were identified only from rims, and given Oxford Archaeology form codes (Booth no date). In addition, vessels were matched with forms in regional typologies, primarily Monaghan's corpus of North Kent and Upchurch pottery (Monaghan 1987), the Camulodunum series (Hawkes and Hull 1947), and Thompson's typology of 'Belgic' forms (Thompson 1982). Where possible, fabrics were assigned codes devised by the Canterbury Archaeological Trust (CAT no date).

\subsection{Fabrics}

The list of fabrics represented is provided below. Detailed descriptions for a number of fabrics can be found in Tomber and Dore (1998), whose National Roman Fabric Reference Collection codes are in parentheses. Fabric quantification is given in Table 1 .

\section{Late Bronze Age/Early Iron Age fabrics}

FLINT. Flint-tempered fabric

SAND. Sand-tempered fabric

\section{Amphorae}

R50. South Spanish amphora fabric (BAT AM 1-3)

R56. South Gaulish amphorae fabric (GAL AM 1-2)

R98. Unsourced amphora fabric
Shelly ware

R69. North Kent/South Essex shelly ware

\section{Late Iron Age/Early Roman fabrics}

LIAB4. Coarse flint-tempered ware

B1. Fine grog-tempered ware (SOB GT)

B2. Coarse grog-tempered ware (SOB GT)

B3. Grog-tempered ware with flint

B5. Grog-tempered ware with sand

B5.1. Grog-tempered ware with shell

B8. Fine sand-tempered ware

B9. Coarse sand-tempered ware

B9.1. Glauconitic Medway Valley ware

B9R. Sandstone-tempered ware

R154. Red-surfaced grog-tempered ware

\section{Fine wares}

B12. Terra Rubra (?GAB TR 1A)

BER12. Terra Nigra (GAB TN 1)

R151. Unsourced red colour-coated ware

\section{Oxidised wares}

R8. Fine sandy oxidised ware

R68. Patchgrove oxidised ware (PAT GT)

R71. Miscellaneous fine oxidised wares

R74. Miscellaneous sandy oxidised ware

White-slipped wares

R18. North Kent fine white-slipped oxidised ware

Reduced wares

R73. Sandy greyware

\section{Samian wares}

R42. South Gaulish samian ware (LGF SA)

White wares

B17. North Gaulish sandy white ware (NOG WH 3)

BER5-10.Unsourced Gaulish white wares

BER15. Organic (?chaff) tempered ware

R75. Miscellaneous white wares

Post-medieval wares

PM. Miscellaneous post-medieval ware

\section{Assemblage composition and pottery supply}

\subsection{Phasing}

Context group dates and stratigraphic phasing allowed the assemblage to be divided into two phases: Late Iron Age (c 50 BC-AD 43/50) and early Roman (c AD 40-70). There was in fact little to separate the phased assemblages from a ceramic perspective; both were dominated by grog-tempered wares and other pottery supplied during the Late Iron Age and the earliest years of the Roman period. Ceramic groups of early Roman date were so dated 
Table 1. Late Iron Age and Roman pottery (MNV: minimum number of vessels; EVE: estimated vessel equivalents)

\begin{tabular}{|c|c|c|c|c|c|c|c|c|}
\hline Ware & Sherds & $\%$ & Weight $(g)$ & $\%$ & $M N V$ & $\%$ & $E V E$ & $\%$ \\
\hline B1 & 1083 & $28 \%$ & 9342 & $19 \%$ & 88 & $31 \%$ & 9.53 & $32 \%$ \\
\hline B12 & 5 & $<1 \%$ & 64 & $<1 \%$ & & & & \\
\hline B17 & 2 & $<1 \%$ & 22 & $<1 \%$ & & & & \\
\hline B2 & 527 & $14 \%$ & 12398 & $25 \%$ & 32 & $11 \%$ & 3.13 & $10 \%$ \\
\hline B3 & 1 & $<1 \%$ & 92 & $<1 \%$ & 1 & $<1 \%$ & 0.18 & $1 \%$ \\
\hline B5 & 47 & $1 \%$ & 425 & $1 \%$ & 4 & $1 \%$ & 0.21 & $1 \%$ \\
\hline B5.1 & 67 & $2 \%$ & 1150 & $2 \%$ & 13 & $5 \%$ & 1.10 & $4 \%$ \\
\hline B8 & 21 & $1 \%$ & 165 & $<1 \%$ & 2 & $1 \%$ & 0.35 & $1 \%$ \\
\hline B9 & 114 & $3 \%$ & 1407 & $3 \%$ & 8 & $3 \%$ & 0.71 & $2 \%$ \\
\hline B9.1 & 501 & $13 \%$ & 5856 & $12 \%$ & 25 & $9 \%$ & 3.96 & $13 \%$ \\
\hline B9R & 649 & $17 \%$ & 9547 & $19 \%$ & 44 & $16 \%$ & 4.11 & $14 \%$ \\
\hline BER12 & 1 & $<1 \%$ & 8 & $<1 \%$ & 1 & $<1 \%$ & 0.05 & $<1 \%$ \\
\hline BER15 & 21 & $1 \%$ & 35 & $<1 \%$ & & & & \\
\hline BER5-10 & 5 & $<1 \%$ & 19 & $<1 \%$ & & & & \\
\hline FLINT & 4 & $<1 \%$ & 32 & $<1 \%$ & & & & \\
\hline LIAB4 & 250 & $7 \%$ & 3316 & $7 \%$ & 28 & $10 \%$ & 2.50 & $8 \%$ \\
\hline PM & 1 & $<1 \%$ & 3 & $<1 \%$ & & & & \\
\hline R151 & 1 & $<1 \%$ & 3 & $<1 \%$ & & & & \\
\hline R154 & 54 & $1 \%$ & 371 & $1 \%$ & 8 & $3 \%$ & 0.99 & $3 \%$ \\
\hline R18 & 2 & $<1 \%$ & 5 & $<1 \%$ & 2 & $1 \%$ & 0.32 & $1 \%$ \\
\hline R42 & 1 & $<1 \%$ & 5 & $<1 \%$ & 1 & $<1 \%$ & 0.05 & $<1 \%$ \\
\hline R50 & 2 & $<1 \%$ & 90 & $<1 \%$ & & & & \\
\hline R56 & 3 & $<1 \%$ & 165 & $<1 \%$ & & & & \\
\hline R68 & 12 & $<1 \%$ & 211 & $<1 \%$ & 1 & $<1 \%$ & 0.03 & $<1 \%$ \\
\hline R69 & 377 & $10 \%$ & 5121 & $10 \%$ & 19 & $7 \%$ & 2.47 & $8 \%$ \\
\hline R71 & 2 & $<1 \%$ & 2 & $<1 \%$ & & & & \\
\hline R73 & 10 & $<1 \%$ & 25 & $<1 \%$ & 1 & $<1 \%$ & 0.08 & $<1 \%$ \\
\hline R74 & 2 & $<1 \%$ & 32 & $<1 \%$ & 1 & $<1 \%$ & 0.09 & $<1 \%$ \\
\hline R75 & 7 & $<1 \%$ & 18 & $<1 \%$ & & & & \\
\hline $\mathrm{R} 8$ & 28 & $1 \%$ & 53 & $<1 \%$ & & & & \\
\hline R98 & 3 & $<1 \%$ & 49 & $<1 \%$ & & & & \\
\hline SAND & 9 & $<1 \%$ & 52 & $<1 \%$ & & & & \\
\hline Totals & 3812 & & 50083 & & 279 & & 29.86 & \\
\hline
\end{tabular}

on account of the usually small amounts of pottery that were attributed with certainty to the Roman period. If the latter were removed, then the groups would be identical in composition to those assigned exclusively to the Late Iron Age. Similarly, most Late Iron Age groups could conceivably date beyond AD 43 , since the principal wares continued to be made after this date. However, it is notable that early Roman context-groups generally belonged to features that were situated higher in the stratigraphic sequence and therefore were later than features containing pottery dated to the Late Iron Age. This suggests that the ceramic phases are reasonably valid when compared with the stratigraphic phasing.

\subsection{The Late Iron Age pottery}

Pottery from groups dated to the Late Iron Age and recovered from features assigned on the basis of stratification to the same period accounted for $61 \%$ of the entire assemblage by EVE (Table 2). Fine grog-tempered ware (B1) formed the largest share of the Late Iron Age group, constituting $27 \%$ by EVE (Table 2). The fabric was available mainly in bead-rimmed jars $(\mathrm{CH})$ and jars
Table 2. Pottery from Late Iron Age context groups (quantification by EVE). ${ }^{*}=$ fabrics present, but with no rim surviving

\begin{tabular}{lccccccc}
\hline Ware & $C$ & $E$ & $H$ & $J$ & $L$ & Total & $\%$ \\
& Jar & Beaker & Bowl & Platter & Lid & EVE & EVE \\
\hline B1 & 3.77 & & 1.06 & & & 4.83 & $27 \%$ \\
B12 & & & & & & $*$ & \\
B17 & & & & & & $*$ & \\
B2 & 1.9 & & 0.45 & & 0.03 & 2.38 & $13 \%$ \\
B3 & & & 0.18 & & & 0.18 & $1 \%$ \\
B5 & 0.14 & & & & & 0.14 & $1 \%$ \\
B5.1 & 0.87 & & & & & 0.87 & $5 \%$ \\
B8 & 0.29 & & & 0.06 & & 0.35 & $2 \%$ \\
B9 & 0.17 & & & & & 0.17 & $1 \%$ \\
B9.1 & 3.2 & 0.27 & 0.07 & & & 3.54 & $18 \%$ \\
B9R & 1.91 & & & & 0.08 & 1.99 & $11 \%$ \\
BER12 & & & & 0.05 & & 0.05 & $<1 \%$ \\
BER15 & & & & & & $*$ & \\
LIAB4 & 1.13 & & & & & 1.13 & $6 \%$ \\
R154 & & & 0.60 & & & 0.60 & $3 \%$ \\
R69 & 1.99 & & & & & 1.99 & $11 \%$ \\
R75 & & & & & & $*$ & \\
R98 & & & & & & $*$ & \\
Total EVE & 15.37 & 0.27 & 2.36 & 0.11 & 0.11 & 18.22 & \\
\% EVE & $84 \%$ & $1 \%$ & $13 \%$ & $1 \%$ & $1 \%$ & & \\
\hline
\end{tabular}


or bowls with everted rims and cordoned or corrugated shoulders (CD/HD), for example Monaghan (1987) type 4F, or Hawkes and Hull (1947) Cam 229. Other forms were present, however, including high-shouldered necked jars (CE), barrel-shaped jars (CB) and narrow-necked jars or flasks (CC). The fabric was variable and ranged from very fine to lumpy and relatively coarse. The division between fabric B1 and its coarse counterpart, B2, was not always clear, with both wares essentially forming a continuum of a single fabric. There was consequently some overlap of forms, with the everted rimmed, corrugated bowl or jar (CD/HD) and bead-rimmed (or the related globular) jar $(\mathrm{CG} / \mathrm{CH})$ appearing in the coarse fabric. However, storage jars (CN), for example Monaghan (1987) type 3D and Thompson (1982) type B1-2, were found only in the coarse fabric. Some grog-tempered fabrics contained additional tempering agents. A bowl with an everted rim and corrugated shoulder (HD) was present in grog and flint-tempered ware (B3), and a similar form (CD) was also available in grog and sand-tempered ware (B5). A globular jar (CG) and a butt beaker (EA) were also recorded in this fabric. Grog and shell-tempered ware (B5.1) was present in the form of bead-rimmed jars $(\mathrm{CH})$, lid-seated jars (CJ) and so-called saucepan jars (CU), the last characterized by thick, bulging walls, an internally thickened rim, and the absence of a neck (Hawkes and Hull 1947, Cam 254). Lid-seated jars were manufactured in the north Kent marshes (Monaghan 1987, type 3L), but were ubiquitous at production sites along the Essex coast, notably at Mucking and West Tilbury (Jones and Rodwell 1973, 22; Drury and Rodwell 1973, 82; Jefferies and Lucy 2016,162 , type AB), and it is possible that the vessels originated there. Red-surfaced grog-tempered ware was a much finer fabric. Forms were restricted to fine dining vessels, including a necked bowl (HD), and a carinated bowl (HA) with cordons and lattice decoration, which may have been inspired by Gallo-Belgic forms, such as the girth beaker Cam 84.

Glauconitic Medway Valley ware (B9.1) was another important category, comprising $18 \%$ by EVE of the Late Iron Age assemblage. Its black-grained and rounded glauconite or greensand inclusions give the ware a distinctive appearance, and even when it contained additional inclusions, notably grog and quartz sand, the ware was easily separated from other fabrics. Rustication in the form of strips or nodules was noted on three fragments. Glauconitic fabrics were well-established in the region, being attested at sites dating to the earlier Iron Age. Glauconitic fabrics accounted for $90 \%$ of the Early-Middle Iron Age assemblage from Eyhorne Street, Hollingbourne, some $15 \mathrm{~km}$ south-east of Leybourne (Jones 2006). The glauconite was available locally, and so the pottery may have been produced near the site. The use of grog with glauconite indicates that grog-tempering traditions were active where glauconitic pottery was made, and so potentially grog-tempered fabrics B1, B2 and others were of local origin (indeed, an over-fired and warped sherd in fabric B5 from pit 1298 is a potential waster from a local manufacturing site). There was a relatively wide range of forms in fabric B9.1. Footrings or low pedestal bases were noted in a number of contexts. Just one footring was found with a rim, which was identified as a carinated bowl (HA), but others are likely to have been part of oval- or globular-bodied jars with everted rims (Couldrey 1984, type 4; Drury 1978, type 13, fig. 38). Wide-mouthed jars with everted rims (CM) resembled these types, and some of the footrings or pedestals are likely to have belonged to them. Such forms have a long chronology; they were, for example, recorded at Eyhorne Street (Jones 2006). Barrel-shaped (CB), globular (CG), and bead-rimmed $(\mathrm{CH})$ jars, as well as storage jars and jars with corrugated shoulders and everted rims (CD), were also represented in the ware. One globular jar had a flaring rim and scored or roughened-surface decoration on its shoulder and body. Vessels other than jars were represented by a sole butt beaker (EA).

A range of fabrics subsumed under the category of sandstone-tempered ware (B9R) account for an $11 \%$ share of the Late Iron Age assemblage. The pottery is handmade, and generally displays dark exterior surfaces and orange-brown interior surfaces. Fabrics are variable, but are generally gritty, containing moderate to abundant quartz sand, moderate amounts of distinctive white or offwhite rock fragments, and occasional chert, glauconite and argillaceous inclusions. On recording, the rock fragments were provisionally identified as ragstone or Kentish Rag, which derives from the Hythe Formation, the northern extent of which lies a short way to the south of the site (the site itself being situated on the Folkestone Formation). However, thin-section analysis by Dr Patrick Quinn at University College London identified the fragments as 'a silicified, cherty, quartz-rich, fine to medium-grained sandstone' (see below). As the Hythe Formation also consists of non-calcareous sandstone, these inclusions are also likely to have been sourced locally. Forms were largely restricted to bead-rimmed jars $(\mathrm{CH})$, often with facets below the rim (Monaghan 1987, type 3G), and globular jars (CH), with a lid (L) also recorded.

Flint-tempered pottery (LIAB4) accounted for $6 \%$ of the Late Iron Age assemblage. The ware comprises a number of fabric variants, but all are united by the presence of white or grey sub-angular to angular flint (and chert) fragments. In addition, the ware contained quartz sand and grog in varying proportions. The ware was available as globular jars (CG), bead-rimmed jars $(\mathrm{CH})$, and jars with everted rims $(\mathrm{CI})$.

Fine and coarse sandy fabrics were present in small quantities. A carinated jar (CF) with an everted rim and a cordon at the base of the neck and a platter were recorded 
in the fine fabric (B8), while a bead-rimmed jar was available in coarser fabric, B9.

North Kent or South Essex shelly ware (R69), which was separated from fabric B5.1 on the basis of its corky appearance and dominance of shell in the fabric, was reasonably well-represented in the Late Iron Age assemblage at $11 \%$ by EVE, although its relatively low quantity compared with contemporaneous assemblages further north, for example south-east of Dartford, where fabric R69 accounted for 17\% (Biddulph 2011, table 5.6), reflects the fact that the source of the pottery was not local. Forms included jars also encountered in fabric B5.1: saucepan-jars (CU), bead-rimmed jars $(\mathrm{CH})$, and lid-seated jars (CJ). Other forms included storage jars (CN) with characteristic herringbone decoration on the shoulder. These are almost certainly a north Kent product (Monaghan 1987, type 3D).

A small quantity of pottery arrived from Gallia Belgica. A decorated fragment from a bowl or perhaps a beaker was recorded in a fine sandy fabric, with frequent black (?sand) and rarer white and mica inclusions (B12). It was unslipped externally, but had a red brown slip on the interior surface. The fabric recalls Pompeian Red ware, but this identification is unlikely on the grounds of form (Pompeian Red ware was available exclusively as dishes and lids). A second sherd had a similar fabric, but was lighter in colour - buff brown, rather than red brown - and had an external red brown slip. Again, the sherd was decorated and probably from a beaker. Ruling out an Italian source, Gallia Belgica seems the most likely origin for both, and the sherds are tentatively identified as Terra Rubra (Tomber and Dore 1998, 17). A platter (Hawkes and Hull 1947, Cam 5) in Terra Nigra (BER12) was a certain product from Gallia Belgica. Additionally, two sherds of a fine sandy white ware (B17) belonged to vessels made in north Gaul. Sherds from an Italian or Gaulish amphora (R98) with a pink, calcareous and micaceous fabric, complete the range of imported wares, although an unsourced whiteware (R75) may be from Gaul. Other fragments of white ware were recorded as an organic-tempered fabric. This was a fine soft, pink white grass or chaff-tempered fabric with uneven surfaces. Its origin is more likely to be local than imported, but in the absence of rims to identify form, little more can be said. It is possible, given its description, that the fragments derive from a briquetage-like vessel.

\subsection{The early Roman pottery}

Context groups assigned to the early Roman period on the basis of ceramic and stratigraphic dating accounted for $32 \%$ of the entire assemblage by EVE (Table 3 ). Like those of the Late Iron Age the groups were dominated by grog-tempered wares. The fine fabric (B1) increased its share to $38 \%$ of the phased assemblage by EVE (Table 3). A more diverse repertoire of forms was recorded. High-shouldered necked jars (CE) were best

Table 3. Pottery from early Roman context groups (quantification by EVE). * = fabrics present, but with no rim surviving

\begin{tabular}{|c|c|c|c|c|c|c|c|c|c|c|}
\hline Ware & $\begin{array}{c}B \\
\text { Flagon } \\
\end{array}$ & $\begin{array}{c}C \\
\text { Jar }\end{array}$ & $\begin{array}{c}E \\
\text { Beaker }\end{array}$ & $\begin{array}{c}F \\
\text { Cup }\end{array}$ & $\begin{array}{c}H \\
\text { Bowl }\end{array}$ & $\begin{array}{c}J \\
\text { Platter }\end{array}$ & $\begin{array}{c}L \\
\text { Lid }\end{array}$ & $\begin{array}{c}M \\
\text { Misc. }\end{array}$ & $\begin{array}{l}\text { Total } \\
\text { EVE }\end{array}$ & $\begin{array}{c}\% \\
E V E \\
\end{array}$ \\
\hline $\begin{array}{l}\text { B1 } \\
\text { B12 } \\
\text { B17 }\end{array}$ & & 2.97 & 0.06 & & 0.59 & & & & $\begin{array}{c}3.62 \\
* \\
*\end{array}$ & $38 \%$ \\
\hline B2 & & 0.65 & & & & & & & 0.65 & $7 \%$ \\
\hline B5 & & & 0.03 & & 0.04 & & & & 0.07 & $1 \%$ \\
\hline $\begin{array}{l}\text { B5.1 } \\
\text { B8 }\end{array}$ & & 0.23 & & & & & & & $\begin{array}{c}0.23 \\
*\end{array}$ & $2 \%$ \\
\hline B9 & & 0.45 & & & & & 0.09 & & 0.54 & $6 \%$ \\
\hline B9.1 & & 0.24 & & & 0.15 & & & & 0.39 & $4 \%$ \\
\hline B9R & & 1.48 & & & & & & 0.04 & 1.52 & $16 \%$ \\
\hline BER15 & & & & & & & & & $*$ & \\
\hline BER5-10 & & & & & & & & & $*$ & \\
\hline LIAB4 & & 0.94 & & & 0.09 & & 0.04 & & 1.07 & $11 \%$ \\
\hline R151 & & & & & & & & & $*$ & \\
\hline R154 & & 0.12 & 0.08 & 0.19 & & & & & 0.39 & $4 \%$ \\
\hline R18 & 0.25 & & 0.07 & & & & & & 0.32 & $3 \%$ \\
\hline R42 & & & & & & 0.05 & & & 0.05 & $1 \%$ \\
\hline R50 & & & & & & & & & $*$ & \\
\hline R56 & & & & & & & & & * & \\
\hline R68 & & 0.03 & & & & & & & 0.03 & $<1 \%$ \\
\hline R69 & & 0.48 & & & & & & & 0.48 & $5 \%$ \\
\hline R73 & & 0.08 & & & & & & & 0.08 & $1 \%$ \\
\hline R74 & & 0.09 & & & & & & & 0.09 & $1 \%$ \\
\hline R75 & & & & & & & & & $*$ & \\
\hline R8 & & & & & & & & & $*$ & \\
\hline R98 & & & & & & & & & $*$ & \\
\hline Total EVE & 0.25 & 7.76 & 0.24 & 0.19 & 0.87 & 0.05 & 0.13 & 0.04 & 9.53 & \\
\hline \% EVE & $3 \%$ & $81 \%$ & $3 \%$ & $2 \%$ & $9 \%$ & $1 \%$ & $1 \%$ & $<1 \%$ & & \\
\hline
\end{tabular}


represented (22\% of forms by EVE in fabric B1). Other jars included narrow-necked (CC), globular (CG), beadrimmed $(\mathrm{CH})$ and lid-seated $(\mathrm{CJ})$ types, and jars with everted rims and corrugated shoulders (CD). A necked bowl (HD, essentially a wider-mouthed variant of CD), a globular bowl (HG), and a beaker (E) were also recorded. The coarse fabric was available mainly in the form of storage jars (CN; Monaghan 1987, type 3D). Other forms comprised bead-rimmed jars $(\mathrm{CH})$ and a corrugated jar (CD). A globular beaker (ED) and bowl (HG) were recorded in grog and sand-tempered ware (B5). Grog and shell-tempered ware (B5.1) was available as bead-rimmed jars and storage jars likely to have originated in north Kent or south Essex. The fine red-surfaced grog-tempered ware (R154) was supplied mainly as dining forms, including a butt beaker (EA), globular beaker (ED) and a cup (FB) that copied the bell-shaped Terra Rubra form Cam 56. In addition, a bead-rimmed jar was recorded.

Sandstone-tempered ware (B9R) continued to make a significant contribution to the assemblage, constituting $16 \%$ by EVE. The bead-rimmed jar $(\mathrm{CH})$ with faceting below the rim (Monaghan 1987, type 3G) remained the fabric's principal form, but there was also a degree of functional specialization. A near-complete strainer or colander (MG) and a base fragment of a second example, both with multiple holes made in the base before firing by the potter, were recorded. Flint-tempered ware (LIAB4) was better represented in this phase than it was in the Late Iron Age assemblage, accounting for $11 \%$ by EVE. A lid (L), globular bowl (HG) and bead-rimmed jars $(\mathrm{CH})$ were recorded in the ware.

Other wares belonging to this ceramic phase made relatively minor contributions to the assemblage. Notably, the amount of glauconitic Medway Valley ware (B9.1) had declined significantly to $4 \%$ by EVE, providing evidence that the use of glauconite had virtually ceased after the Roman conquest. Some of the forms present in this phase were identical to those represented in the Late Iron Age: globular $(\mathrm{CG})$ and bead-rimmed $(\mathrm{CH})$ jars, and a carinated bowl (HA), but the dramatic drop in quantity suggests that production had all but ceased. Unlike fabric B9R, the glauconitic fabric barely survived into the Roman period. The quantity of North Kent/South Essex shelly (R69) ware had also declined. A barrel-shaped jar (CB), beadrimmed jar, and a saucepan-type jar (CU) were recorded. Contrastingly, the proportions of sand-tempered fabrics B8 and B9 had little altered since the Late Iron Age. A bead-rimmed jar was seen in fabric B9.

What especially distinguishes the early Roman assemblage from the Late Iron Age group is the presence, albeit minor, of a range of Roman-period wares. One or more of these wares were recorded in every context group dated to this phase. Potters in the north Kent marshes supplied a butt beaker (EA; Monaghan 1987, type 2B) and ring-necked flagon (BA; Monaghan 1987, type 1E1/2) in a white-slipped oxidised ware (R18), probably after
AD 50. (The identification of the flagon fabric is a little doubtful, as voids seen on the surface are not typical of the Upchurch fabric). A jar rim occurs in Patchgrove grog-tempered ware (R68). The extent of pre-conquest production is unknown, but the ware, manufactured in west Kent, only achieved wide distribution after AD 43 (Pollard 1987, 39). The small amount of sandy greyware that was present, mainly comprised body sherds. The sole identified vessel, an oval-bodied hook-rimmed necked jar (CD), was problematic in terms of date, since the form is more typical of the second century onwards (Monaghan 1987, type 3H). However, it was associated with grogtempered ware and other first century pottery, and so a later first century date may still be appropriate. A beadrimmed jar $(\mathrm{CH})$ was recorded in the oxidised equivalent of sandy greyware (R74). Fine oxidised (R8) and white wares (R75) were present, but no forms recognised.

Samian ware made a small contribution to the assemblage. A rim sherd from a South Gaulish Drag. 18 platter was recorded. Amphorae fabrics became more diverse. The pink, calcareous and micaceous fabric (R98) present in the Late Iron Age group was also noted in the Roman assemblage. This was joined by a South Gaulish fabric (R56), probably belonging to a Gauloise wine amphora, and a South Spanish fabric (R50) from a Dressel 20 olive oil container. North Gaulish and other Gaulish white wares (B17 and BER5-10) were present, as were fragments of the putative Terra Rubra fabric (B12) seen in the Late Iron Age assemblage. It is possible that some of these fabrics (R98 and B12 particularly) were part of the same vessels recorded in the earlier phase, and that their occurrence was residual. Fabric R151, a fine sandy fabric with a grey core and interior surface, frequent small voids and occasional clay pellets or grog, and a micaceous orange surface with a red-brown slip, is of unknown source.

\section{Vessel use}

Evidence of vessel use was recorded in the form of burning, wear and trimmed or perforated sherds. A burnt deposit on the external surface of a shell-tempered ware bead-rimmed jar from ditch 1107 suggests that the vessel had been placed on a hearth and used for cooking. Another shell-tempered ware jar, in this case a saucepan jar type, has carbonized deposits on the exterior surface below the rim. The vessel had presumably been used for cooking, but this may have been a secondary purpose. The exterior surface of body sherds belonging to the same vessel had a greyish white coating, and given the Thameside source of the pottery may be a salt-related deposit, with the vessel perhaps having reached the site as a salt container. Another jar, made in a glauconite and grog fabric, was severely burnt, becoming light and porous. The storage jar was found within a charcoal rich deposit in pit 1139, and no doubt had been subject to the high heat of a hearth or oven. 
A further jar, a cordoned vessel in a coarse grog-tempered ware from pit 1298, was similarly burnt, though in this case the jar had warped and discoloured.

Three vessels showed evidence of re-use. A base from a fine grog-tempered pedestal jar or bowl from ditch 3007 had been trimmed around the broken edge that formerly joined the wall of the jar, and was also perforated. The piece is likely to have been reused as a spindle-whorl. A jar in coarse grog-tempered ware from pit 1299 was perforated through its base after firing. A vessel in fabric B9R from ditch 1385 had holes made before and after firing. This was a bead-rimmed jar, but had multiple perforations in the base, which had been made before firing. Clearly the vessel was intended as a colander or strainer. During its use, however, a larger perforation was punched through the centre of the base.

\section{Patterning in pottery deposition}

Pottery was deposited almost exclusively into pits and ditches, with much smaller quantities entering other features, these being postholes, tree-throws and layers (Table 4). In overall quantities, ditches contained more pottery than pits. In part, this is likely to be due to the relatively small number of pits compared with the potential availability of space in ditches for deposition/ accumulation; ditches had a greater chance of receiving pottery. However, individual ditch fills also contained more pottery than did pit deposits. Each ditch fill contained on average 36.6 sherds and 0.5 EVEs, compared with 20.7 sherds and 0.33 EVEs for each pit fill. There was, then, a general preference for depositing pottery into ditches. There was, though, no significant difference between the pit and ditch assemblages in terms of composition. Both were dominated by jars: $84 \%$ by EVE in ditches, $77 \%$ in pits. Both contained similar quantities of beakers and bowls. Cups and platters were present only in ditches, but as there were so few of these types, the difference is unlikely to be meaningful. The mean sherd weight statistic (weight divided by count) gives an indication of sherd size and preservation. Excluding the anomalous high mean sherd weight of pottery from tree-throws, which derives from a single large and heavy storage jar sherd within a very small assemblage, sherds recovered from pits were generally larger than those from ditches. This suggests that pottery present in pit groups had been subject to fewer episodes of breakage through such means as trampling,

Table 4. Incidence of pottery deposition amongst principal feature types $(M S W=$ mean sherd weight (weight/count)

\begin{tabular}{lrcc}
\hline Feature type & Count & Weight $(g)$ & MSW \\
\hline Tree throw & 8 & 372 & 46.5 \\
Pit & 764 & 12791 & 16.7 \\
Ditch & 2762 & 35071 & 12.7 \\
Posthole & 80 & 474 & 6 \\
Layer & 4 & 10 & 2.5 \\
\hline
\end{tabular}

disturbance and relocation before final deposition, or that the groups had been sealed once deposited, thereby curtailing much further fragmentation or weathering. Pits and ditches also received most pottery along the West Malling-Leybourne bypass (A228; see Fig. 1). There, however, the sherd size was reversed, with pit groups having a mean sherd weight of $10.5 \mathrm{~g}$ and ditches $14.8 \mathrm{~g}$ (Jones 2009, table 1.5). In any case, all these weights are high compared with Queen Elizabeth Square, Maidstone, whose assemblage, recovered from field ditches away from settlement, had an overall mean sherd weight of 9.6g (Biddulph 2004), and the small assemblage from White Horse Stone, Aylesford, which had an average sherd weight of $5.8 \mathrm{~g}$ and was recovered from trackway ditches (Stansbie 2006). The higher sherd weight from Leybourne Grange (and the bypass site) suggests that the features from which the pottery was collected were located relatively close to the focus of domestic occupation and areas where freshly broken pottery was originally discarded.

\section{Site status and function}

The arrival of Gaulish and possibly Italian imports during the Late Iron Age and conquest period indicates that the settlement was situated within wider trade networks. The pottery included a putative Terra Rubra beaker, a Terra Nigra dish, white ware flagons and wine and olive oil amphorae. After $c$ AD 50, the settlement saw the arrival of a samian platter from southern Gaul. Imitations of Gallo-Belgic prototypes were also available, including a grog-tempered cup that copied a Terra Rubra form, a platter in a fine sandy fabric, butt beakers in fine grogtempered ware and other fabrics, and a finely-made carinated bowl that probably imitated a Gallo-Belgic girth beaker. While such pottery suggests that the inhabitants were familiar with Roman (or, rather, Gallo-Roman) dining and cooking traditions, its presence alone is a poor indicator of the extent to which continental traditions were practised and whether the occurrence of these types was representative of site status and function. A clearer picture emerges, however, with the use of other indicators. Evans $(2001,28)$ observed that assemblages from basic rural sites of Iron Age and Roman date tended to be dominated by jars, whereas the assemblages from higher-status sites are more diverse, in particular having increased proportions of drinking and dining forms. The emphasis on jars at Iron Age sites is evident from Early to Middle Iron Age assemblages at Eyhorne Street (Jones 2006) and White Horse Stone, Aylesford (Morris 2006).

On this basis, we can see from a comparison with a number of sites in central and north-west Kent that the proportion of jars at Leybourne Grange is relatively high, certainly when compared with Queen Elizabeth Square, Maidstone (although the high-status element of that site is boosted by the survival of a single complete 
Table 5. Percentages of forms in Late Iron Age and early Roman assemblages (quantification by EVE, except West Malling-Leybourne bypass and Springhead by vessel count)

\begin{tabular}{|c|c|c|c|c|c|c|c|c|c|}
\hline Site & $\begin{array}{c}\text { B } \\
\text { Flagons }\end{array}$ & $\begin{array}{c}C \\
\text { Jars }\end{array}$ & $\begin{array}{c}E \\
\text { Beakers }\end{array}$ & $\begin{array}{c}F \\
\text { Cups }\end{array}$ & $\begin{array}{c}H \\
\text { Bowls }\end{array}$ & $\begin{array}{c}J \\
\text { Platters }\end{array}$ & $\begin{array}{c}L \\
\text { Lids }\end{array}$ & Other & Total \\
\hline Leybourne Grange & 1 & 85 & 2 & 1 & 11 & 0.5 & 1 & $\mathbf{0}$ & 29.86 \\
\hline West Malling-Leybourne bypass & & 97 & & & 2 & 0.5 & 0.5 & & 123 \\
\hline Thurnham villa (Late Iron Age) & 3 & 90 & 2 & 1 & 1 & & & 3 & 6.28 \\
\hline Snarkhurst Wood, Hollingbourne & & 85 & 1 & & 5 & 1 & & 8 & 9.53 \\
\hline A2/A282, Dartford & & 82 & 16 & & 1 & & & & 8.81 \\
\hline Springhead (Late Iron Age) & & 72 & 10 & 1 & 10 & 7 & 1 & & 157 \\
\hline White Horse Stone, Aylesford & & 68 & & & 31 & & & & 0.54 \\
\hline Treatment Pond, Dartford & 14 & 67 & 4 & 8 & & 5 & & & 2.15 \\
\hline Queen Elizabeth Square, Maidstone & 15 & 56 & 7 & 2 & 6 & 10 & 3 & & 6.88 \\
\hline Springhead (early Roman) & 3 & 49 & 11 & 1 & 16 & 12 & 7 & 1 & 4920 \\
\hline
\end{tabular}

Data: Jones 2009, table 1.7 (West Malling-Leybourne bypass); Lyne 2006a, table 3 (Thurnham); Lyne 2006b, table 2 (Snarkhurst Wood); Biddulph 2011, tables 5.6-7 (A2/A282); Seager Smith et al. 2011, table 15 (Springhead); Stansbie 2006, table 4 (White Horse Stone); Biddulph 2011, table 5.8 (Treatment Pond); Biddulph 2004, table 3 (Queen Elizabeth Square).

flagon rim), but is notably lower than the nearby bypass site (Table 5). Of interest, too, is the diversity of the form range at Leybourne Grange, which, incorporating a number of dining forms, is comparable to Queen Elizabeth Square, the Treatment Pond (Dartford), and Springhead. In contrast, the form range from the bypass site and other sites, including Snarkhurst Wood (Hollingbourne) and Thurnham, is more restricted.

Taken together, Leybourne Grange is best placed in a lower-status category, its assemblage being consistent with a rural settlement. While its inhabitants had access to a range of tablewares and imported pottery typically recorded at higher-status sites, the quantities suggest that this pottery did not form part of the inhabitants' everyday cooking and dining practices. There are differences in composition between the assemblage and that from the bypass site, but these do not appear too significant when compared with, say, Springhead, a Late Iron Age shrine complex and Roman town. The supply of imported wares to Leybourne Grange made little impact on the overall balance of the site's assemblage. Its diversity in vessel types suggests that, compared with the bypass site, pottery was being used for a wider range of functions or that specialist forms were available to serve functions that would otherwise have been performed by jars and bowls. However, such forms were present in small quantity, with quantities not matching Springhead. It is worth noting that the pottery from the Quarry Wood Camp, Loose, a site often suggested to be an oppidum or an element of an oppidum, that might be expected to be clearly differentiated from low-status rural sites in terms of its ceramics, did not appear to include a greater range of imported wares compared with Leybourne Grange (Kelly 1971, 79-84). The comparison is inexact, since no quantification has been offered for the oppidum, but it raises the possibility that differences between sites of various status in the Medway Valley during the Late Iron Age were much flatter compared with the Roman period. Of incidental interest is the assemblage from Queen
Elizabeth Square. The site was regarded as a relatively low-status rural site (Booth and Howard-Davis 2004, 24), but its pottery, when compared with Leybourne Grange and Springhead, suggests something more middle ranking in the early Roman period, perhaps a larger or nucleated settlement.

\section{Petrographic analysis}

\section{Sean Patrick Quinn}

\subsection{Introduction and methodology}

Thin section petrographic analysis was undertaken on a single sherd of pottery (taken from a strainer or colander (SF 1005) from context 1230) identified as fabric B9R. In addition to characterising its petrographic composition, analysis was undertaken in order to test the suggestion that it contained lithic inclusions of 'Kentish Rag'.

A small piece of the sherd was removed with a rotating diamond blade then impregnated with epoxy resin. The impregnated subsample was prepared as a standard petrographic thin section at the Institute of Archaeology, University College London (Quinn 2013, 23-33) and studied at magnifications of $25-400 \times$ under the polarising light microscope. The fabric of the sherd was characterized in terms of its dominant inclusions as well as the nature of its clay matrix and voids. An interpretation was made of the raw materials from which it was manufactured, as well as its paste preparation and firing technology. Specific attention was given to the possible presence of Kentish Rag inclusions, as well as other components suggested by macroscopic study, including glauconite and grog.

\subsection{Petrographic characterization}

The sherd consisted in thin section of a medium-grained fabric characterized by disaggregated silicified sandstone inclusions in a non-calcareous, vitrified clay matrix (Fig. 4A and C). The aforementioned inclusions consist of fragments of silica cemented sandstone, as well as 


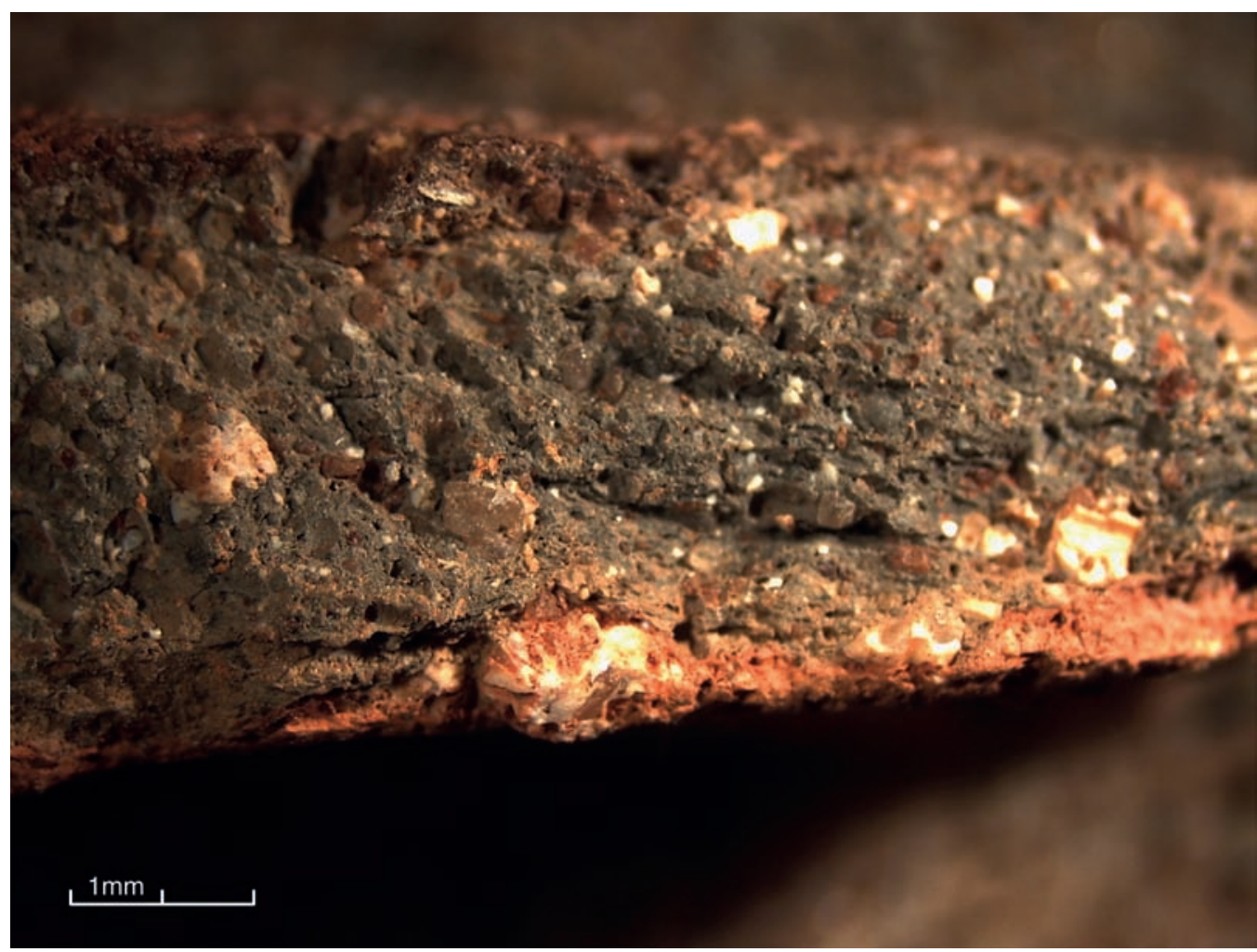

Figure 3. Photograph of break across sherd from vessel SF 1005 (fabric B9R), context 1230.

the disaggregated quartz class and matrix of this. This is composed of sparse fine to medium sand-sized rounded clasts of quartz and polycrystalline quartz in chert cement (Fig. 4B). The last is frequently chalcedonic and can be iron-stained. The high abundance of matrix in the sandstone means that sizeable fragments of this material exist (Fig. 4D). A couple of sandstone inclusions have an opaque matrix so could be classified as ironstone (Fig. 4E). The fragments of matrix and sandstone have an angular appearance, suggesting that they had been crushed and added as temper. The sample contains sparse fine sand-size rounded opaque inclusions which could be glauconite. A couple of clay-rich argillaceous features with sharp to merging boundaries occur in the prepared thin section (Fig. 4F). The sample has a non-calcareous clay matrix containing very fine quartz and sparse mica. It has low to moderate porosity composed of meso- and macro-elongate voids. The vessel from which the sherd originated was highly fired $\left(>850^{\circ} \mathrm{C}\right)$ above the point of vitrification. It has thin oxidised margins and a dark core.

\subsection{Discussion}

The inclusions that characterize the sherd have a distinctive composition that suggest the use of a specific rock type during its manufacture. This was a silicified, cherty, quartzrich, fine to medium-grained sandstone. The name 'Kentish Rag' or Kentish ragstone is used in the building trade to describe hard, grey sedimentary rock, quarried in the Weald of Kent, that has been used for construction since at least the Roman times. This material comes from the Early Cretaceous Hythe Formation and is composed of 'sandy limestone consisting of rounded detrital grains of quartz and the green mineral glauconite, cemented by calcite' (Worssam and Tatton-Brown 1993, 93). This rock outcrops in the Maidstone area and is extracted to the present day. The inclusions within the Leybourne Grange sherd are not composed of limestone, so do not appear to match the description of Kentish Rag. The material in the sample is not at all calcareous, but has siliceous cement instead.

In the western Weald, the Hythe Formation consists of non-calcareous sandstones (Gallois 1965, 32; Worssam and Tatton-Brown 1993, 94). This suggests that the Hythe Beds could be a possible source for the rock fragments within the sherd. However, such material cannot be termed 'Kentish Rag'. Worssam and Tatton-Brown (1993, 94-5) report that layers of chert can occur within ragstone, including in the Maidstone area. This siliceous rock may be a candidate for the material found within the Leybourne Grange sherd. The presence of sand class within the inclusions rules out the use of flint nodules from the nearby chalk.

The presence of glauconite, suggested from the macroscopic study of the sherd seems to be supported by the rounded sand-sized opaque inclusions seen in thin section. It is not clear whether crushed pottery or 'grog' was added to the paste used to manufacture the point from which the Leybourne Grange sherd originated. One of the rare clay-rich argillaceous features present in the sample 


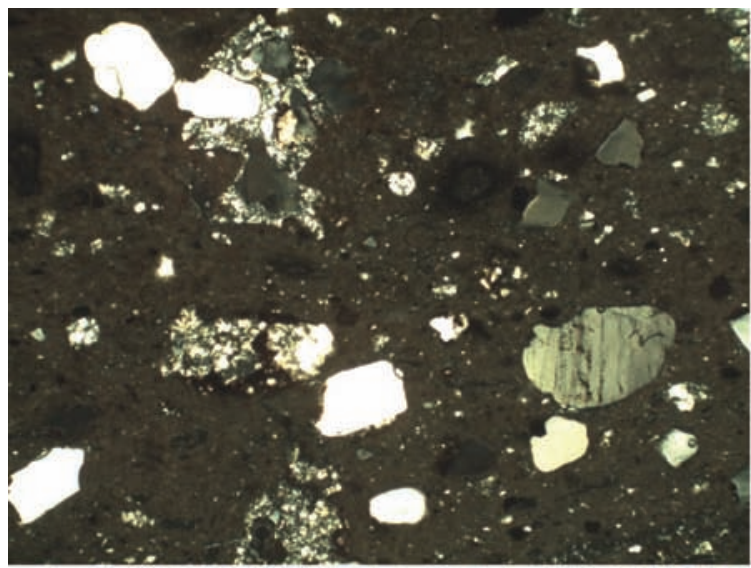

A - General view of the fabric

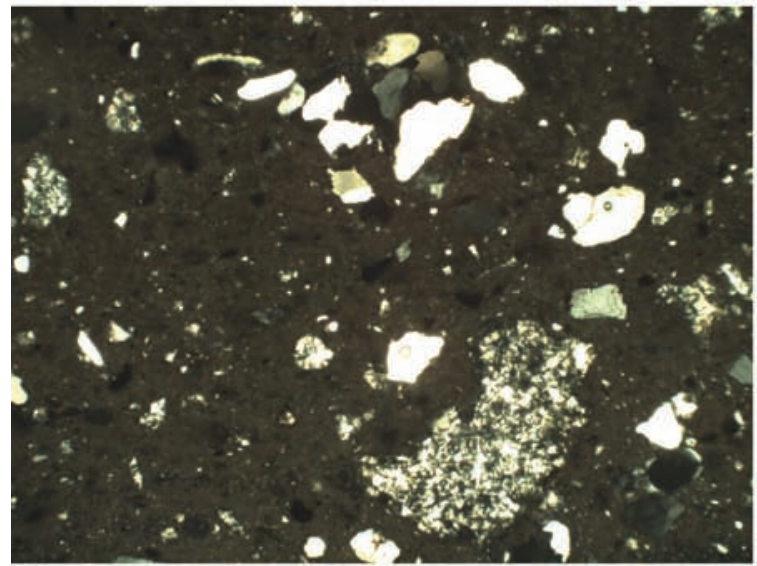

C - General view of the fabric

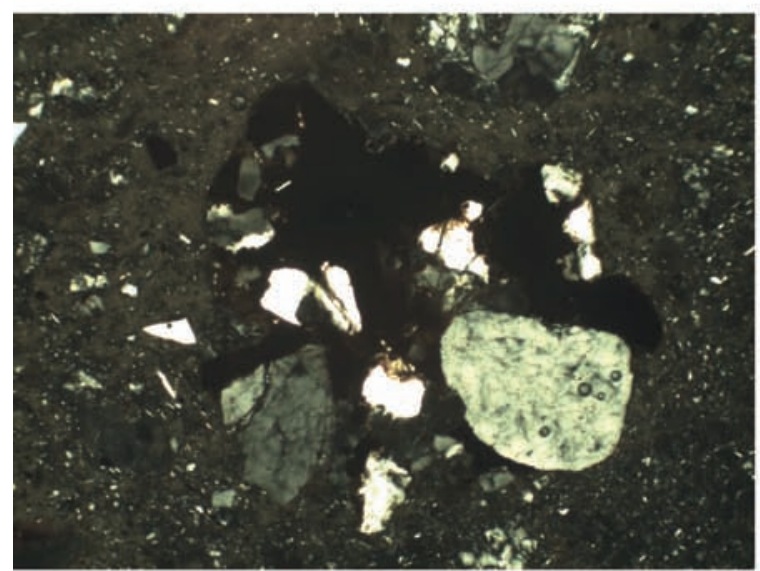

E - Iron-cemented sandstone

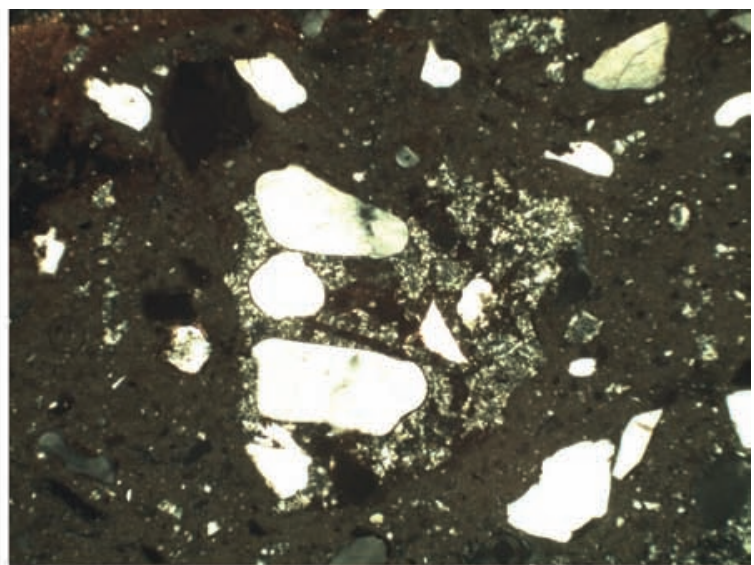

B - Silicified sandstone inclusion

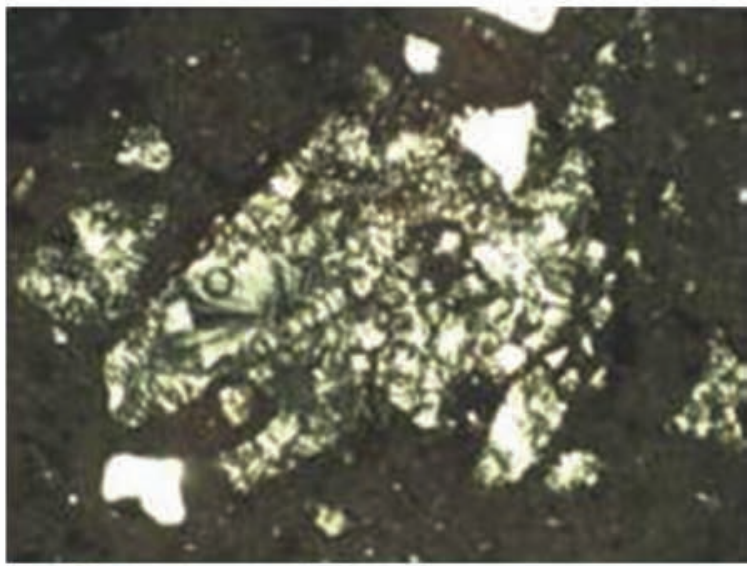

D - Chalcedony inclusion

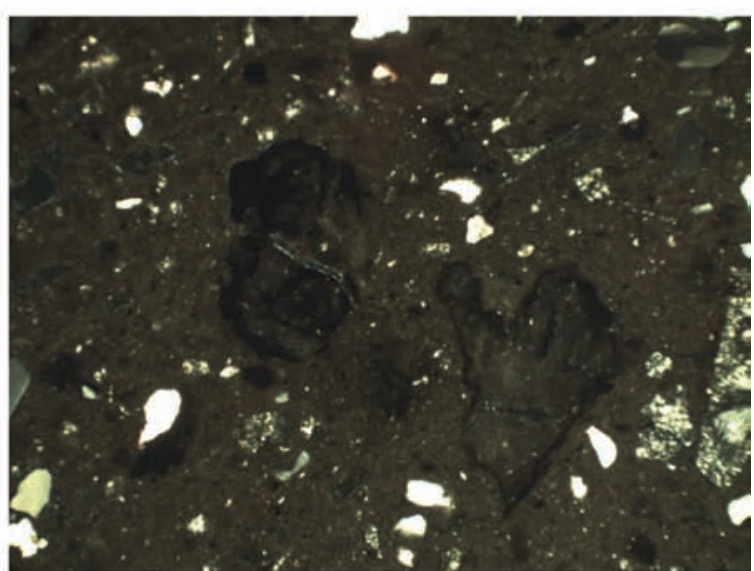

$\mathrm{F}$ - Argillaceous inclusions

Figure 4. Thin section photomicrographs of sherd from vessel SF 1005, context 1230, in fabric B9R. Images taken in crossed polars. Image width $=2.9 \mathrm{~mm}$, except $D$ and $E=1.45 \mathrm{~mm}$.

is angular and has sharp boundaries. However, the other is rounded with merging boundaries.

\section{Sandstone-tempered pottery: A local and short-lived phenomenon?}

The angular nature of the sandstone inclusions confirms that the sandstone had been deliberately crushed and added to the clay as temper. The use of sandstone as an occasional tempering agent is notable, not having been previously recognised in Late Iron Age and Roman pottery in the region, although pottery containing what was identified as crushed malmstone, a form of sandstone, was recorded in the MoLAS evaluation at the site (Blackmore $2003,42)$. This group took the second largest share of the evaluation assemblage, and it is likely that it is identical to 
fabric B9R. Excavations along the nearby West MallingLeybourne bypass (A228; see Fig. 1), however, identified no pottery with sandstone inclusions (Jones 2009). It is possible that sandstone fragments were present, but not identified, although the facetted bead-rimmed jars in which fabric B9R was principally available were not apparently identified on the bypass site, suggesting that the absence of the ware is genuine.

The source of the sandstone is uncertain, though a local origin is likely. Sandstone is found within the Hythe Formation, which is part of the Lower Greensand Group and extends in a curving band from the south Kent coast at Sandgate to the Surrey/Kent border via Ashford, Maidstone, Sevenoaks and Westerham (Worssam and Tatton-Brown 1993, 95). The Hythe Formation has a complex geology that encompasses a variety of lithologies, but is well-known for the seam of calcareous limestone or ragstone that outcrops in the Maidstone area. Ragstone has been quarried at least since the Roman period, the use of the stone in the buildings of Roman London and Kent being well-documented. The village of Leybourne sits on the northern edge of the Hythe Formation (the modern M20, M25 and M26 motorways in Kent essentially mark the boundary of the Lower and Upper Greensand groups). Worssam and Tatton-Brown (1993, fig. 2) show the sandstone occurring largely in the Weald west of Sevenoaks, around Westerham and further west some $25 \mathrm{~km}$ west of Leybourne, while chert, which is also a component of fabric B9R, occurs more widely between Sevenoaks and Little Chart, south-east of Maidstone (see also Blows 2011, 7-9). The source of the sandstone may therefore have been west of Leybourne, beyond the Sevenoaks area and away from the quarries in the Maidstone area, for example at Quarry Wood in Loose, Boughton Monchelsea and Allington, that were exploited in the Roman period.

A siliceous, greyish white cherty sandstone is, however, also a component of the Folkestone Formation, on which Leybourne Grange sits. Outcrops of the stone were exploited in the Wrotham-Borough Green area $c$ $10 \mathrm{~km}$ west of Leybourne during the medieval and later periods, and there is known as Ightham Stone and Oldbury Stone (Blows 2011, 10). On the grounds of distance and composition, the Folkestone Formation is a more likely source for both the chert (which was also present in fabric LIAB4) and the sandstone. In any case, the use of the sandstone would seem to be unrelated to the origins of the Roman ragstone industry.

While ragstone was exploited for significant structural use from the Roman period onwards, potentially any variation of hard rock within the Hythe and Folkestone Formations is useful and would have been extracted from prehistoric times onwards regardless of precise composition. Small, shallow quarries, dug with hand tools and dating to the medieval period, are known in west Kent
(Simon Elliott pers. comm.), and the sandstone in the Leybourne Grange pottery may have derived from similar opportunistic, small-scale quarrying. Whether the stone would have been extracted by the potters themselves, who could have chipped small amounts from the exposed rock, or acquired by the potters as a by-product of unrelated quarrying activity, is uncertain. There is some question of whether the potters were local to Leybourne or worked in West Kent closer to the source of the sandstone. It may be noted that Patchgrove ware (R68), typically recorded as storage jars, as is the case at this site, is conventionally assigned a west Kent source on the basis of distribution (Tomber and Dore 1998, 167). It is possible that the potters responsible for Patchgrove ware were also involved in the manufacture of fabric BR9. So far, however, fabric BR9 has a very restricted distribution away from the potential sources of the sandstone in the Sevenoaks or Wrotham/Borough Green areas, although it is possible that inclusions identified on superficial examination as, say, flint or chert in pottery found closer to the source are in fact sandstone, and so the distribution could be wider. On current evidence, however, it appears likely that potters local to Leybourne Grange were responsible for procuring the sandstone, or else itinerant potters brought the sandstone from its source to the Leybourne area to manufacture pottery there.

Whether local or not the potters began using sandstone in the Late Iron Age and continued to use it into the Roman period. The increase in the proportion of fabric B9R evident in the Roman period is interesting, and may explain the absence of sandstone in the pottery of the bypass site. There, very little post-conquest material was recorded (Jones 2009, 21), and essentially activity had ceased by the mid-first century AD. The use of sandstone inclusions may therefore have been a phenomenon that began at the very end of the Late Iron Age when the bypass site had largely been abandoned. Indeed, from a ceramic perspective, there is little to separate the pre- and post-conquest groups if confirmed post-conquest material is absent, and the possibility that all the pottery from Leybourne Grange was deposited after AD 43 cannot be entirely excluded. Settlement activity at Leybourne Grange itself ceased during the mid/late first century AD. The paucity of North Kent fine wares or Upchurch wares (Monaghan 1987) - the white-slipped fabric (Monaghan 1987, fabric N4) is poorly represented, while the reduced fabric (Monaghan 1987, fabric N1) is absent - is especially telling and points to a terminal date for the settlement no later than $c$ AD 70 .

The apparent absence of sandstone inclusions in later Roman assemblages found on other sites in the region points very strongly to the use of sandstone being short-lived. The use of the sandstone may relate to a period of experimentation in the choice of tempers at a time of significant change in pottery repertoires, styles and technology and the emergence of Romanized 

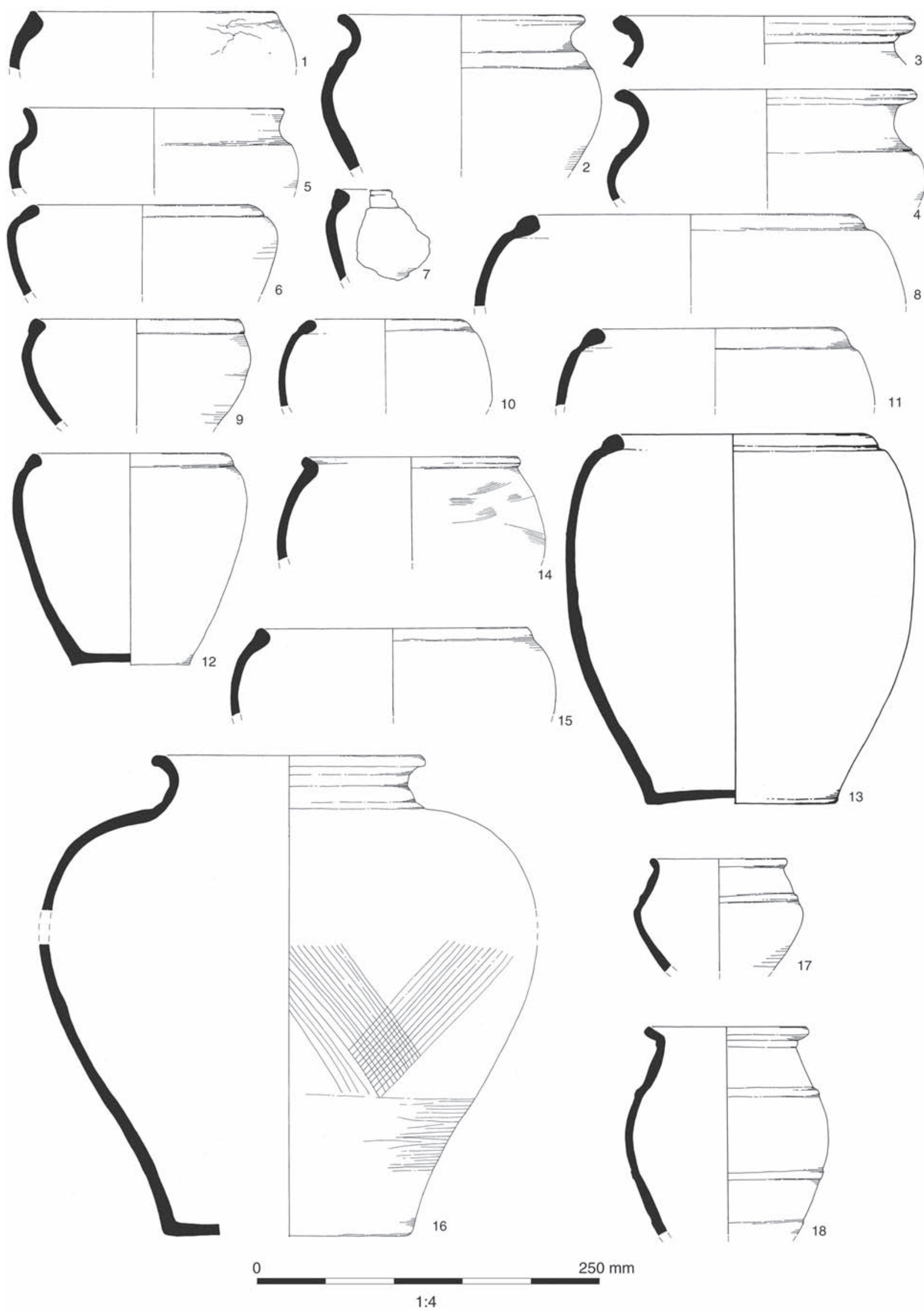

Figure 5. Pottery, catalogue nos 1-18. 

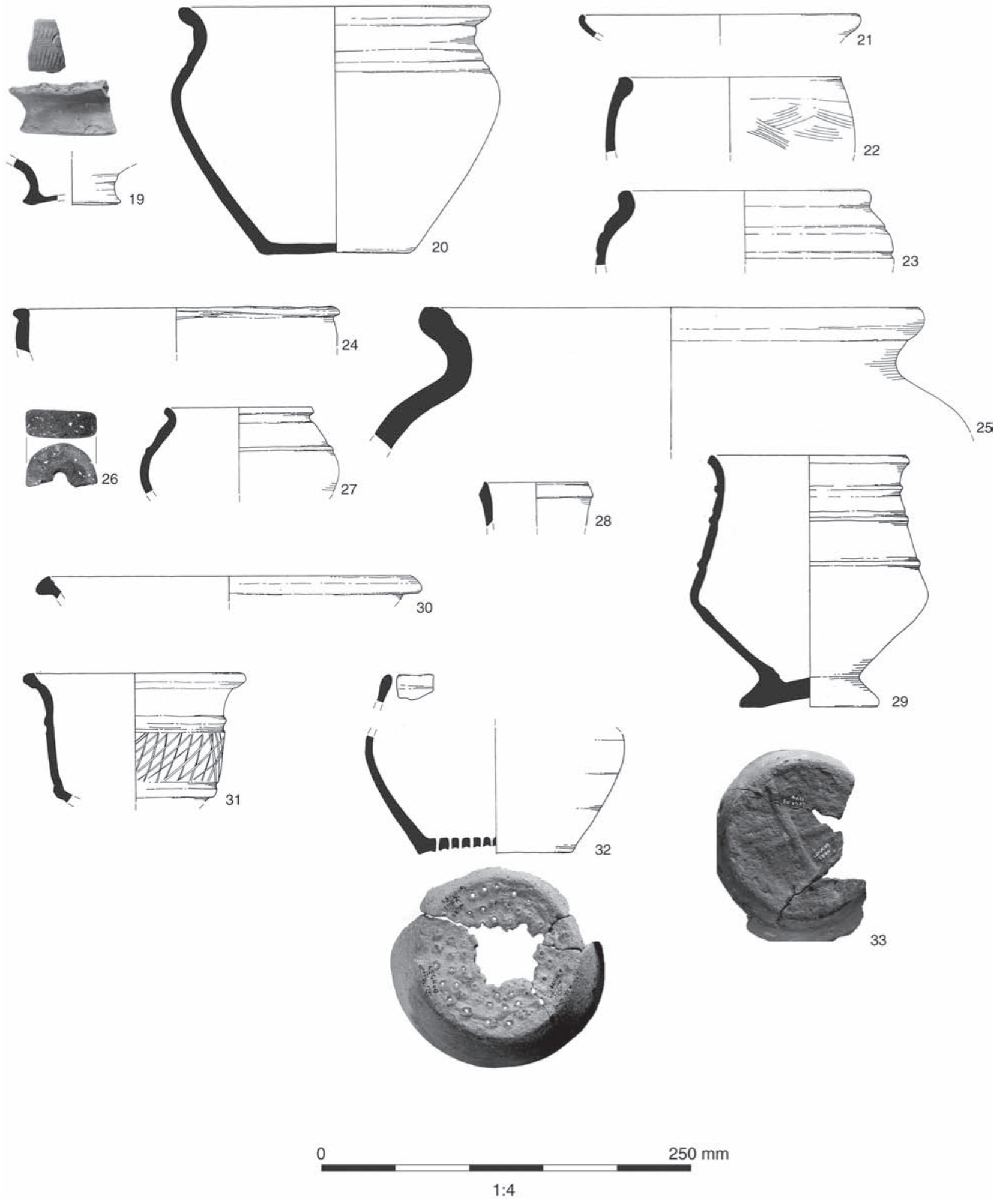

Figure 6. Pottery, catalogue nos 19-33.

ceramic traditions, However, re-examination of existing pottery assemblages from the region, and possibly further petrographic analysis, would be required to demonstrate that view conclusively.

\section{Catalogue of the illustrated pottery}

The illustrated vessels offer a snapshot of pottery supply to the site or show a range of intrinsically interesting pieces. Dates given are for deposition, not production or use. 
Context 1210, segment 1211, ditch 1381;

\section{c AD 10-50}

1. Saucepan jar (CU); grog and shell-tempered ware (B5.1)

2. Everted-rim jar (CD) with corrugated shoulder and burnished rim, neck and shoulder, Thompson 1982, type B1-3; coarse grog-tempered ware (B2)

3. Everted-rim jar (CD); coarse grog-tempered ware (B2)

4. High-shouldered, necked and cordoned jar (CE) with burnished neck and shoulder; coarse grog-tempered ware (B2)

5. Everted-rim jar (CD) with burnished zone on rim and neck; grog and sand-tempered ware (B5)

6. Globular jar (CG) with burnished shoulder; sandstonetempered ware (B9R)

7. Bead-rimmed jar $(\mathrm{CH})$, grog and sand-tempered ware (B5)

8. Bead-rimmed jar $(\mathrm{CH})$; sandstone-tempered ware (B9R)

9. Bead-rimmed jar $(\mathrm{CH})$; sandstone-tempered ware (B9R)

10. Bead-rimmed jar $(\mathrm{CH})$; sandstone-tempered ware (B9R)

11. Bead-rimmed jar $(\mathrm{CH})$; sandstone-tempered ware (B9R)

12. Bead-rimmed jar $(\mathrm{CH})$; sandstone-tempered ware (B9R)

13. Bead-rimmed jar $(\mathrm{CH})$; sandstone-tempered ware (B9R)

14. Bead-rimmed jar (CH), Monaghan 1987, type 3F3; North Kent/South Essex shelly ware (R69)

15. Bead-rimmed jar $(\mathrm{CH})$; grog and shell-tempered ware (B5.1)

16. Storage jar $(\mathrm{CN})$, burnished on shoulder, Thompson 1982, type B1-2; coarse grog-tempered ware (B2)

17. Butt beaker (EA) or necked jar (CE), cordoned neck, overall burnishing; glauconitic Medway Valley ware (B9.1), with additional grog and quartz sand

18. Butt beaker (EA); glaucontic Medway Valley ware (B9.1), with additional grog

19. Beaker in fine sandy buff-brown fabric with external red-brown slip, perhaps Terra Rubra (B12)

20. Necked bowl (HD), with corrugated neck and shoulder, Thompson 1982, type D1-4; coarse grogtempered ware (B2)

21. Platter (JC), fine sandy ware (B8)

\section{Context 1020, segment 1019, ditch 1381;} c 50 BC-AD 50

22. Barrel-shaped (CB) or bead-rimmed $(\mathrm{CH})$ jar, with combed or scored decoration on body; glauconitic Medway Valley ware (B9.1)

23. Globular jar (CG) with grooved shoulder; glauconitic Medway Valley ware (B9.1)
24. Bead-rimmed jar $(\mathrm{CH})$; glauconitic Medway Valley ware (B9.1)

25. Storage jar $(\mathrm{CN})$; glauconitic Medway Valley ware (B9.1)

26. Spindle whorl, shaped and perforated before firing; glauconitic Medway Valley ware (B9.1)

\section{Other pottery}

27. Globular jar (CG), with cordon on shoulder, Monaghan 1987, type 3E0; glauconitic Medway Valley ware (B9.1). Context 1292, segment 1211, ditch 1381; c 50 BC-AD 50.

28. Bell-shaped cup (FB), copying Cam 56; fine redsurfaced grog-tempered ware. Context 1244, segment 1384, ditch 1385; c AD40/50.

29. Carinated bowl (HA) with cordoned body and pedestal base; glauconitic Medway Valley ware (B9.1). Context 1229, segment 1227, ditch 1385; c AD 40/50.

30. Platter (Cam 5), Terra Nigra (BER12). Context 1232, segment 1233, ditch 1385; c AD 40-55.

31. Carinated bowl (HA), with burnished lattice between cordons, possibly copying Gallo-Belgic girth beaker; fine red-surfaced grog-tempered ware (R154). Context 1292, segment 1211, ditch 1281; c 50 BC-AD 50.

32. Strainer/colander (MG), with base pierced before firing, then perforated with larger central hole after firing; sandstone-tempered ware (B9R), oxidised surfaces. SF 1005, context 1230, segment 1227, ditch 1385; $c$ AD 40/50.

33. External surface of jar base showing cross motif in relief formed from applied strips before firing, possibly to strengthen the base; sandstone-tempered ware (B9R). Context 1374, pit 1299; c 50 BC-AD 50.

\section{Conclusion}

The pottery assemblage recovered from Leybourne Grange in Kent dates to the Late Iron Age and early Roman transition. The near-absence of North Kent fine wares (Monaghan 1987) and comparison with other assemblages in the region suggest that the pottery was deposited no later than $c$ AD 70. The assemblage was dominated by grog-tempered wares and jars and bowls that display evidence of utilitarian use, although a more diverse repertoire was evident in groups assigned to the early Roman period. The pottery had been deposited mainly into enclosure and field boundary ditches that were associated with a basic-level rural settlement. However, imports such as amphorae and samian and other traded pottery such as Patchgrove ware suggest that the site was located into wider trading networks. A notable aspect of the assemblage was the presence of pottery tempered with rock fragments initially thought to be ragstone, but identified by petrographic analysis as sandstone. Sandstone is found within the Hythe 
Formation, which forms part of the geology of the site, and therefore the pottery is likely to have been made close to the settlement. Despite the availability of the tempering material, however, sandstone-tempered pottery appears to have been a local and short-lived phenomenon, not being recognised away from the site and in later Roman assemblages in the region. The use of sandstone may represent a period of experimentation during a time of change in ceramic traditions, but further scientific analysis of assemblages in the region may be required before this can be confirmed.

\section{Acknowledgements}

The author is indebted to Taylor Wimpey SW Thames for funding the archaeological fieldwork and post-excavation programme. Special thanks are owed to Paul Mckeown, formerly technical manager of Taylor Wimpey, and Ben Connop, Taylor Wimpey's senior design and planning executive, for ensuring that the project proceeded smoothly. The author is also grateful to Wendy Rogers, Senior Archaeological Officer for Kent County Council, for her support. The fieldwork was managed by Timothy Haines and latterly by David Score. The post-excavation project was managed by the author. The pottery was drawn by Magdalena Wachnik. Georgina Slater and Charles Rousseaux prepared the site figures, which were based on plans digitised by Mark Littlewood and Anne Kilgour. The author is grateful to Dr Patrick Quinn of UCL Institute of Archaeology for his rapid and expert petrographic analysis, and to the two referees for their helpful comments and suggestions. The site code for the excavation is LEGR09; the code for the watching brief is LEGR11.

\section{Bibliography}

Biddulph, E. 2004. Iron Age and Roman pottery, in P. Booth and C. Howard-Davis Prehistoric and Romano-British Settlement at Queen Elizabeth Square, Maidstone, Oxford Archaeology Occasional Paper 11, Oxford, 15-21.

Biddulph, E. 2011. Late Iron Age and Roman pottery, in A. Simmonds, F. Wenban-Smith, M. Bates, K. Powell, D. Sykes, R. Devaney, D. Stansbie and D. Score Excavations in North-West Kent 2005-2007: One Hundred Thousand Years of Human Activity in and around the Darent Valley, Oxford Archaeology Monograph 11, Oxford, 116-24.

Biddulph, E. 2017. A late Iron Age and early Roman settlement at Leybourne Grange, West Malling, Kent, Kent Archaeological Reports online. http://www.kentarchaeology.org.uk/10/ Leybourne_Grange_Oxford_Archaeology.pdf

Blackmore, L. 2003. Pottery assessment, in MoLAS Leybourne Grange Hospital, Birling Road, Leybourne, Kent: An archaeological evaluation report, unpublished report by Museum of London Archaeology Service, 41-7.

Blows, J. 2011. Strategic Stone Study: A building stone atlas of Kent, London.

Booth, P. no date. Oxford Archaeology Roman pottery recording system: an introduction (revised June 2007), unpublished document, Oxford Archaeology.
Booth, P. and Howard-Davis, C. 2004. Prehistoric and RomanoBritish Settlement at Queen Elizabeth Square, Maidstone, Oxford Archaeology Occasional Paper 11, Oxford.

CAT no date. Canterbury Ceramics 2: The processing and study of excavated pottery, unpublished report by Canterbury Archaeological Trust.

Couldrey, P. 1984. The Iron Age pottery, in B. Philp Excavations in the Darent Valley, Kent, Dover, 38-71.

Drury, P.J. 1978. Excavations at Little Waltham, 1970-71, CBA Research Report 26, London.

Drury, P.J. and Rodwell, W.J. 1973. Excavations at Gun Hill, West Tilbury, Essex Archaeology and History, 5, 48-112.

Evans, J. 2001. Material approaches to the identification of different Romano-British site types, in S. James and M. Millett (eds) Britons and Romans: Advancing an archaeological agenda, CBA Research Report 125, York, 26-35.

Gallois, R.W. 1965. British Regional Geology: The Wealden District, Keyworth, Nottingham.

Hawkes, C.F.C. and Hull, M.R. 1947. Camulodunum: First Report on the Excavations at Colchester, 1930-1939, Reports of the Society of Antiquaries of London 14, London.

Jefferies, R. and Lucy, S. 2016. Romano-British pottery, in S. Lucy and C. Evans, with R. Jefferies, G. Appleby and C. Going, Romano-British Settlement and Cemeteries: Mucking Excavations by Margaret and Tom Jones, 1965-1978, Oxford, 154-99.

Jones, G.P. 2006. The later prehistoric pottery from Eyhorne Street, Hollingbourne, Kent (420 68+100-68+500 99), CTRL Specialist Report Series, Archaeological Data Service, http://archaeologydataservice.ac.uk/catalogue/ adsdata/arch-335-1/dissemination/pdf/PT2_Spec_Reps/01_ Ceramics/CER_research_reports/CER_LaterPrehistoricPot/ CER_LaterPrehistoricPot_Text/CER_LPR_EYH_text. pdf?CFID $=45 \&$ CFTOKEN $=454 \mathrm{ECBCD}-4089-404 \mathrm{~A}$ BD2E40E91FF417B6

Jones, G.P. 2009. Later prehistoric and Roman pottery, in P. Andrews, K.E. Dinwiddy, C. Ellis, A. Hutcheson, C. Phillpotts, A.B. Powell and J. Schuster Kentish Sites and Sites of Kent: A Miscellany of Four Archaeological Excavations, Wessex Archaeology Report 24, Salisbury, 18-31.

Jones, M.U. and Rodwell, W.J. 1973. The Romano-British pottery kilns at Mucking, Essex Archaeology and History, 5, 13-47.

Kelly, D.B. 1971. Quarry Wood Camp, Loose: a Belgic oppidum, Archaeologia Cantiana, 86, 55-84.

Lyne, M. 2006a. The late Iron Age and Roman pottery from Thurnham Roman Villa, Thurnham, Kent, CTRL Specialist Report Series, Archaeological Data Service, http://archaeologydataservice.ac.uk/catalogue/adsdata/ arch-335-1/dissemination/pdf/PT2_Spec_Reps/01_ Ceramics/CER_research_reports/CER_RomanPot/CER_ RomanPot_Text/CER_ROM_THM_text.pdf?CFID= 45 \& C F T O K E N = 454 E C B C D - $4089-404$ A BD2E40E91FF417B6

Lyne, M. 2006b. The late Iron Age and Roman Pottery from Snarkhurst Wood, Hollingbourne, Kent (ARC SNK99), CTRL Specialist Report Series, Archaeological Data Service, http://archaeologydataservice.ac.uk/ catalogue/adsdata/arch-335-1/dissemination/pdf/ PT2_Spec_Reps/01_Ceramics/CER_research_reports/ CER_RomanPot/CER_RomanPot_Text/CER_ROM_ 
SNK_text.pdf?CFID $=45 \&$ CFTOKEN=454ECBCD-4089404A-BD2E40E91FF417B6

Monaghan, J. 1987. Upchurch and Thameside Roman Pottery: A ceramic typology for northern Kent, 1st to 3 rd centuries $A D$, BAR British Series 173, Oxford.

Morris, E.L. 2006. The late prehistoric pottery from White Horse Stone, Pilgrim's Way, Boarley Farm and Boarley Farm West, Boxley, Kent, CTRL Specialist Report Series, Archaeology Data Service, http://archaeologydataservice.ac.uk/ archiveDS/archiveDownload? $\mathrm{t}=$ arch-335-1/dissemination/ pdf/PT2_Spec_Reps/01_Ceramics/CER_research_reports/ CER_LaterPrehistoricPot/CER_LaterPrehistoricPot_Text/ CER_LPR_WHS_text.pdf

Pollard, R.J. 1987. The Roman Pottery of Kent, Maidstone.

Quinn, P.S. 2013. Ceramic Petrography: The interpretation of archaeological pottery and related artefacts in thin section, Oxford.

Seager Smith, R., Brown, K.M. and Mills, J.M. 2011. The pottery from Springhead, in E. Biddulph, R. Seager Smith and J. Schuster, Settling the Ebbsfleet Valley. High Speed 1 Excavations at Springhead and Northfleet, Kent: The Late Iron Age, Roman, Saxon, and Medieval landscape. Volume 2. Late Iron Age to Roman finds reports, Oxford and Salisbury. Stansbie, D. 2006. The late Iron Age and Roman pottery from White Horse Stone, Boxley, Kent, CTRL Specialist Report Series, Archaeological Data Service, http://archaeologydataservice. ac.uk/catalogue/adsdata/arch-335-1/dissemination/pdf/ PT2_Spec_Reps/01_Ceramics/CER_research_reports/ CER_RomanPot/CER_RomanPot_Text/CER_ROM_WHS_ text.pdf?CFID $=45 \&$ CFTOKEN $=454 \mathrm{ECBCD}-4089-404 \mathrm{~A}$ BD2E40E91FF417B6

Thompson, I. 1982. Grog-tempered 'Belgic' Pottery of SouthEastern England, BAR British Series 108, Oxford.

Tomber, R. and Dore, J. 1998. The National Roman Fabric Reference Collection: A Handbook, Museum of London Archaeology Services, Monograph 2, London.

Worssam, C. and Tatton-Brown, T. 1993. Kentish Rag and other Kent building stones, Archaeologia Cantiana, 112, 93-126. 